\title{
Study into tillage-mulch package for production of sweet potato (Ipomoea batatas L) effect on soil properties and yield
}

\author{
Adebisi $\mathrm{S}^{1}$, Adekiya A.O ${ }^{2 *}$, Ojeniyi S.O ${ }^{1}$ \\ 1. Department of Crop, Soil and Pest Management, Federal University of Technology, Akure, Ondo State. Nigeria \\ 2. Department of Crop and Soil Sciences, Landmark University, P.M.B. 1001, Omu-Aran, Kwara State, Nigeria \\ *Corresponding author email:adekiya2009@yahoo.com
}

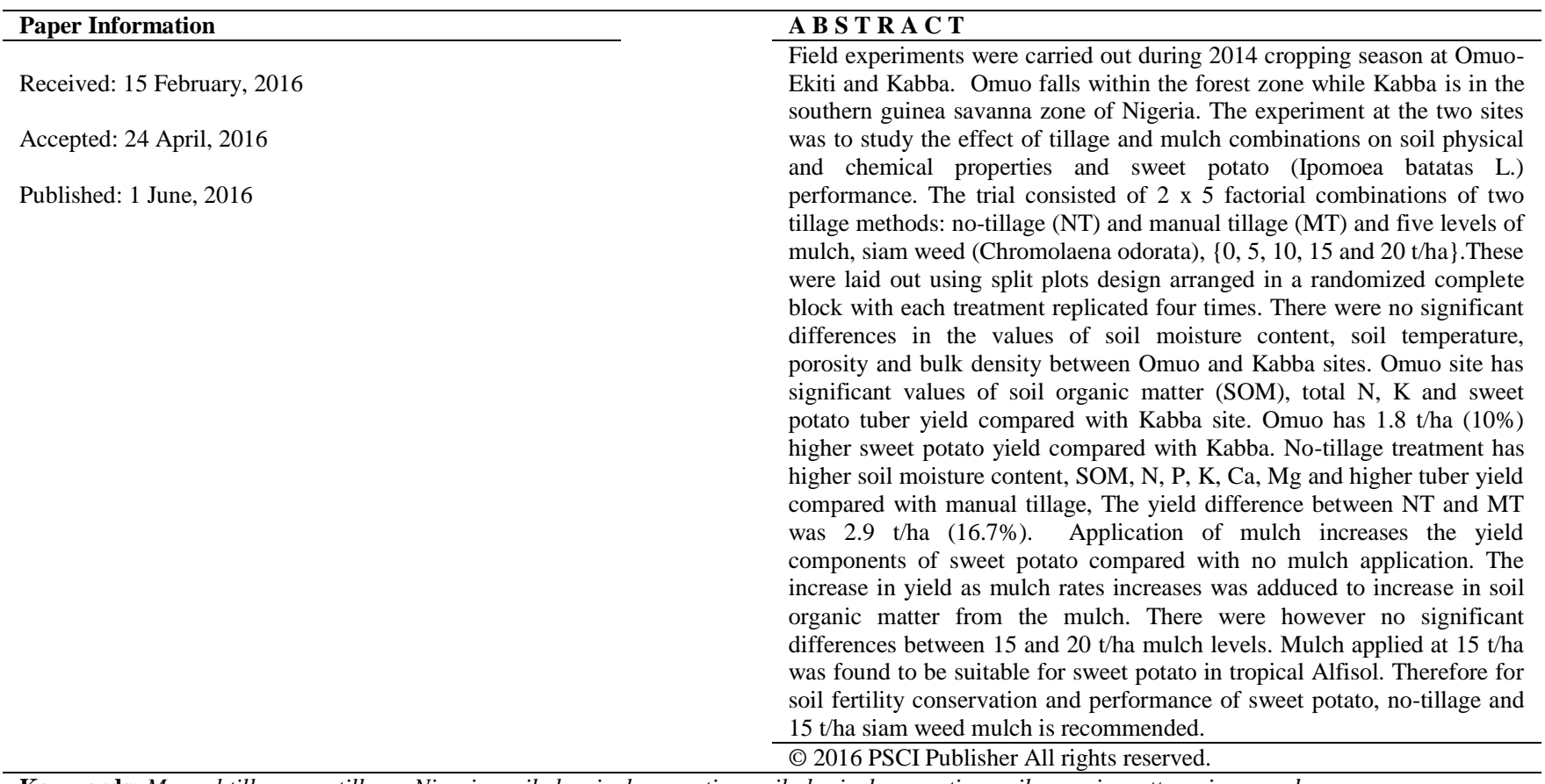

Key words: Manual tillage; no-tillage; Nigeria; soil chemical properties; soil physical properties; soil organic matter; siam weed.

\section{Introduction}

Sweet potato (Ipomoea batatas L.) is produced largely in the tropics. The tuber is eaten boiled, fried and baked or made into syrup and also serves as raw materials for the manufacture of starch, glucose and alcohol (Yasmin et al., 2007). The leaves are also used as vegetables in some communities in Nigeria and widely used as fodder for livestock. The tuber is an excellent source of anti-oxidants and carotenes chiefly in the orange flesh colour varieties thus providing cheap and rich source of vitamin A for poor people (Woolfe, 1992).

Despite the numerous benefits, most tropical tuber crops especially sweet potato is not managed optimally, thus resulting in low yields. Among the most important factors affecting yield of crops like sweet potato include continuous cultivation on the same land which leads to soil nutrient exhaustion, physical degradation and low yield. More so sweet potato like any other tuber crop is a heavy feeder exploiting greater volume of soil for nutrient and water (Osundare, 2004). Study into appropriate soil management package for enhanced productivity of sweet potato is rare although the fragile nature of tropical soils required appropriate and integrated soil management for sustaining high soil and crop productivity.

Sweet potato is often planted on ridges and mounds, whereas it is established by research that no-tillage is important in soil and water conservation and has been favourable to crops performance in the humid zones (Adekiya and Ojeniyi, 2002; Agbede, 2008). Tillage affects soil properties such as temperature, moisture content, bulk density, porosity and infiltration which affect crops performance. If intensively performed or mechanised it causes rapid degradation of soil physical, chemical and biological qualities especially in humid zones of southern Nigeria. Hence there is need to study effects on no-till method in sweet potato cultivation. 
Mulch on the other hand is a layer of plant residue applied to the surface soil to conserve moisture and improve soil fertility (Akanbi and Ojeniyi, 2007). It is a common practice recommended for tropical small holder farming. The technique improves biotic activity and adds nutrients thereby improving soil fertility and crops yield.

In order to alleviate the problems of low soil fertility and soil quality affecting yield of sweet potato with repetitive cultivation, there is the need to develop an organic no-till bared soil management for sustainable production of the crop. It is already established that total dependence on chemical fertilizer has failed to sustain crop production in the tropics (Ojeniyi, 2000; Ano and Agwu, 2005). The importance of no-tillage and mulching in soil and water conservation, growth and yield of crops in Nigeria has been reported (Agele et al., 1999). However research information is scarce on response of sweet potato to tillage and mulching in different agro ecological zones of Nigeria. Ossom et al. (2001) in Papua New Guinea reported the benefits of applying mulches to sweet potato to stabilize yield.The main objective of this work was to develop tillage- mulch package for sustaining soil quality and yield of sweet potato.

\section{Materials and methods}

Field experiments were carried out during 2014 cropping season at Omuo-Ekiti (Lat $7^{\circ} 31^{\prime} \mathrm{N}$ long $5^{\circ} 49^{\prime} \mathrm{E}$ ) and Kabba (Lat $7^{\circ} 51^{\prime} \mathrm{E}$ long $6^{\circ} 45^{\prime} \mathrm{E}$ ). Omuo falls within the forest zone where the rich tropical forest once thrived while Kabba is in the southern guinea savanna zone of Nigeria. The top of the soil at both sites were sandy loam. The two sites were both Alfisol. Omuo has a rainfall of $1250-1460 \mathrm{~mm}$ per annum and mean temperature of $27^{\circ} \mathrm{C}$. The site has tropical humid vegetation with distinct wet and dry seasons. The wet season is from late March to October with little dry season in August. Kabba has an annual rainfall of between 1000-1256 mm, with an annual mean temperature of $32^{\circ} \mathrm{C}$. Rainfall is also bimodal. The experiment at the two sites was to study the effect of tillage and mulch combinations on soil properties and sweet potato (Ipomoea batatas L.) performance.

\section{Experimental design and treatment}

The experiments were laid out using split plots design arranged in a randomized complete block with each treatment replicated four times. The area used in each site was $697 \mathrm{~m}^{2}$ in size having a total of 8 main plots and each main plot has 5 sub-plots. Each main plot measured $19 \times 2.5 \mathrm{~m}$ with discard of $3 \mathrm{~m}$ within the main plots and $2 \mathrm{~m}$ in between sub-plot and $2 \mathrm{~m}$ round the whole plot. The trial consisted of $2 \times 5$ factorial combinations of two tillage methods \{(1) Notillage, NT i.e. manual clearing with cutlass and weeds removed from plots before planting on flat without primary or secondary tillage operation and (2) Manual tillage, MT i.e. preparation of ridges by heaping the soil surface layer using the traditional hoe after cleared weeds were removed from the plots $\}$ and five levels of mulch, siam weed (Chromolaena odorata), $\{0,5,10,15$ and $20 \mathrm{t} / \mathrm{ha}\}$. These were combined to make 10 treatments. Tillage operation was carried out in May at the two sites.

\section{Planting of sweet potato and application of siam weed mulch}

After tillage operations, planting of $30 \mathrm{~cm}$ sweet potato vines variety TIS87/0087 obtained from National Root Crop Research Institute, Umudike, Nigeria was done in May 2014 at the spacing of 0.5 x $1 \mathrm{~m}$ while mulch application followed a day after the planting. Fresh siam weed collected from a nearby farm and hedge containing green tender stems and the leaves equivalent to $0,5,10,15$ and $20 \mathrm{t} /$ ha was applied to cover the soil. Weeding operation was done manually at 3 and 8 weeks after planting at each site

\section{Determination of soil properties}

One month after planting sweet potato / mulch application, determination of certain soil physical properties in all plots at the two sites commenced and this was done at one- month interval on four occasions. Six samples were collected at $0-10 \mathrm{~cm}$ depth from each plot using a steel cone sampler and were used for evaluation of bulk density, total porosity and gravimetric water content after oven-dried at $100^{\circ} \mathrm{C}$ for $24 \mathrm{~h}$. Total porosity was calculated from the values of bulk density and particle density. Soil temperature was determined at $15.00 \mathrm{~h}$ with a soil thermometer inserted to $10 \mathrm{~cm}$ depth. Six readings were made per plot at each sampling time at 1-month interval and mean data were computed.

Prior to commencement of experiment, soil samples randomly collected from $0-20 \mathrm{~cm}$ depth were thoroughly mixed inside a plastic bucket to form a composite which was later analysed for physical and chemical properties. At the harvest in each location, another set of composite samples were collected per plot basis and similarly analysed for routine chemical analysis as described by Carter (1993). The soil samples were air-dried and sieved using a $2 \mathrm{~mm}$ sieve before making the determinations. Soil organic matter was determined by the procedure of Walkley and Black using the dichromate wet oxidation method (Nelson and Sommers, 1996), total N was determined by micro-Kjeldahl digestion method (Bremner, 1996), available P was determined by Bray-1 extraction followed by molybdenum blue colorimetry (Frank et al., 1998). Exchangeable $\mathrm{K}, \mathrm{Ca}$ and $\mathrm{Mg}$ were extracted using $1.0 \mathrm{~N}$ ammonium acetate. Thereafter, $\mathrm{K}$ was determined using a flame photometer and $\mathrm{Ca}$ and $\mathrm{Mg}$ were determined by EDTA titration method (Hendershot and Lalande, 1993). Soil $\mathrm{pH}$ was determined in soil water (1:2) medium using the digital electronic $\mathrm{pH}$ meter. Particle size analysis was done using Bouyoucos hydrometer method (Sheldrick and Hand Wang, 1993). Soil bulk density was determined using the core method (Campbell and Henshall, 1991). 


\section{Yield components}

Ten plants from the sub-plots were randomly selected for the yield determination. Yield parameters assessed included tuber length, tuber diameter, number of tubers, tuber girth and tuber weight. These were determined at harvest $(5$ months after planting)

\section{Statistical analysis}

The data collected were subjected to analysis of variance (ANOVA) using the SAS and Microsoft Office Excel 2007 packages and treatment means were compared using the Duncan's multiple range test (DMRT).

\section{Results}

The data shown in Table 1 are the results of the physical and chemical properties of the sites before experimentation. The soils at both sites are sandy loam and slightly acidic. The soil bulk densities were high, though Kabba site higher than Omuo site. At both sites, the organic matter and total $\mathrm{N}$ were low. Available P was moderate. Exchangeable $\mathrm{K}$ was adequate in Omuo and low in Kabba site. Exchangeables $\mathrm{Ca}$ and $\mathrm{Mg}$ were adequate at both sites according to the standard recommended for crop production in ecological zones of Nigeria (Akinrinde and Obigbesan, 2000)

Table 1: Soil physical and chemical properties of the sites before experimentation

\begin{tabular}{lll}
\hline Parameter & Omuo & Kabba \\
\hline Sand $(\%)$ & 66 & 66 \\
Silt $(\%)$ & 18 & 15 \\
Clay $(\%)$ & 16 & 19 \\
Textural class & Sandy loam & Sandyloam \\
Bulk density $\left(\mathrm{Mg} / \mathrm{m}^{3}\right)$ & 1.31 & 1.42 \\
Total porosity $(\%)$ & 50.6 & 46.4 \\
$\mathrm{pH}($ water $)$ & 5.6 & 5.9 \\
Organic matter $(\%)$ & 2.38 & 2.45 \\
Total N $(\%)$ & 0.15 & 0.13 \\
Available $\mathrm{P}(\mathrm{mg} / \mathrm{kg})$ & 12.1 & 10.3 \\
Exchangeable $\mathrm{K}(\mathrm{cmol} / \mathrm{kg})$ & 0.18 & 0.14 \\
Exchangeable Ca $(\mathrm{cmol} / \mathrm{kg})$ & 3.2 & 2.9 \\
Exchangeable $\mathrm{Mg}(\mathrm{cmol} / \mathrm{kg})$ & 1.2 & 0.9 \\
\hline
\end{tabular}

Table 2: Effect of sites, tillage methods and mulch rates on soil physical properties $(0-10 \mathrm{~cm}$ depth $)$

\begin{tabular}{|c|c|c|c|c|}
\hline & Moisture content (\%) & $\begin{array}{l}\text { Temperature } \\
\left({ }^{\circ} \mathrm{C}\right)\end{array}$ & $\begin{array}{l}\text { Total porosity } \\
(\%)\end{array}$ & $\begin{array}{l}\text { Bulkdensity } \\
\left(\mathrm{Mg} / \mathrm{m}^{3}\right)\end{array}$ \\
\hline \multicolumn{5}{|l|}{ Site $(\mathrm{S})$} \\
\hline Omuo & $11.96 \mathrm{a}$ & $31.0 \mathrm{a}$ & $55.5 \mathrm{a}$ & $1.18 \mathrm{ab}$ \\
\hline Kabba & $11.86 \mathrm{a}$ & $31.5 \mathrm{a}$ & $54.0 \mathrm{ab}$ & $1.22 \mathrm{a}$ \\
\hline \multicolumn{5}{|l|}{ Tillage method(T) } \\
\hline No-tillage (NT) & $12.03 \mathrm{a}$ & $30.9 \mathrm{ab}$ & $54.3 \mathrm{ab}$ & $1.21 \mathrm{a}$ \\
\hline Manual tillage (MT) & $10.20 \mathrm{~b}$ & $31.6 \mathrm{a}$ & $55.8 \mathrm{a}$ & $1.17 \mathrm{ab}$ \\
\hline \multicolumn{5}{|l|}{ Mulch rate $(\mathrm{M})(\mathrm{t} / \mathrm{ha})$} \\
\hline 0 & $11.39 \mathrm{a}$ & $34.7 d$ & $50.6 \mathrm{e}$ & $1.31 \mathrm{e}$ \\
\hline 5 & $12.34 b$ & $32.6 \mathrm{c}$ & $54.7 \mathrm{~d}$ & $1.20 \mathrm{~d}$ \\
\hline 10 & $14.90 \mathrm{c}$ & $31.4 \mathrm{~b}$ & $55.8 \mathrm{c}$ & $1.17 \mathrm{c}$ \\
\hline 15 & $15.85 \mathrm{~d}$ & $29.1 \mathrm{a}$ & $57.4 \mathrm{~b}$ & $1.13 b$ \\
\hline 20 & $17.10 \mathrm{e}$ & $28.6 \mathrm{a}$ & $59.2 \mathrm{a}$ & $1.08 \mathrm{a}$ \\
\hline $\mathrm{S} \times \mathrm{T}$ & ns & ns & Ns & Ns \\
\hline $\mathrm{S} \times \mathrm{M}$ & ns & ns & Ns & Ns \\
\hline $\mathrm{T} \times \mathrm{M}$ & ns & ns & Ns & Ns \\
\hline $\mathrm{S} \times \mathrm{T} \times \mathrm{M}$ & ns & ns & Ns & Ns \\
\hline
\end{tabular}

Values followed by similar letters under the same column are not significantly different at $p=0.05$ according to Duncan's multiple range test $(\mathrm{DMRT}): \mathrm{ns}=$ not significant

\section{Effect of sites, tillage methods and mulch application on soil physical properties}

Table 2 shows the results of the effect of sites, tillage methods and siam mulch applications on the soil physical properties. There were no significant differences in the values of soil moisture content, temperature, porosity and bulk density between Omuo and Kabba sites. However, Omuo site had slightly lower bulk density and higher porosity compared with Kabba site.

Among tillage methods, NT had significantly higher soil moisture content compared with MR. There were no significant differences in soil temperature, porosity and bulk density between NT and MR.

Application of mulch increased soil moisture content, porosity and reduced soil temperature and bulk density significantly compared with no application of mulch. Increasing mulch levels from $0-20$ t/ha increased moisture content and porosity of the soil. Similarly increasing mulch level decreases soil temperature significantly, however there were no significant differences between application of mulch at 15 and $20 \mathrm{t} / \mathrm{ha}$ in terms of soil temperature. There were significant reduction of bulk density of the soils as mulch levels increases from 0-20 t/ha. There were no significant differences in the 
interaction between site (S) and tillage method (T) i.e. $\mathrm{S} \mathrm{x} \mathrm{T}$, sites and mulch (M) i.e. $\mathrm{S} x \mathrm{M}$, tillage and mulch i.e. $\mathrm{T} \times \mathrm{M}$ and $\mathrm{S} \times \mathrm{T}$ x M for moisture content, soil temperature, porosity and bulk density.

\section{Effect of sites, tillage methods and mulch application on soil chemical properties}

Table 3 shows the results of the effect of sites, tillage methods and mulch application on soil chemical properties. Soil pH did not produce any significant difference between Omuo and Kabba sites. Omuo site had significantly higher values of soil organic matter ( $\mathrm{SOM}$ ), total $\mathrm{N}$ and $\mathrm{K}$ compared with Kabba site. The values of $\mathrm{P}, \mathrm{Ca}$ and $\mathrm{Mg}$ were not significantly different between both sites.Tillage methods also influenced soil chemical properties significantly with NT having higher values of SOM, N, P, K, Ca and Mg compared with MT. The values of soil pH were not significantly different between NT and MT soils.

Application of mulch increased soil $\mathrm{pH}, \mathrm{SOM}, \mathrm{N}, \mathrm{P}, \mathrm{K}, \mathrm{Ca}$ and $\mathrm{Mg}$ significantly compared with no application of mulch. Increasing level of mulch from 0-20 t/ha increased soil pH, SOM, N, P, K, Ca and Mg. However, for all soil nutrients, except $\mathrm{pH}$, application of mulch at 15 and $20 \mathrm{t} /$ ha did not produce any significant different. SOM, N and $\mathrm{K}$ only produced significant interaction between $\mathrm{S} x \mathrm{~T}$ and $\mathrm{T}$ x M. Other interactions have no significant effect.

Table 3: Effect of sites, tillage methods and mulch rates on soil chemical properties

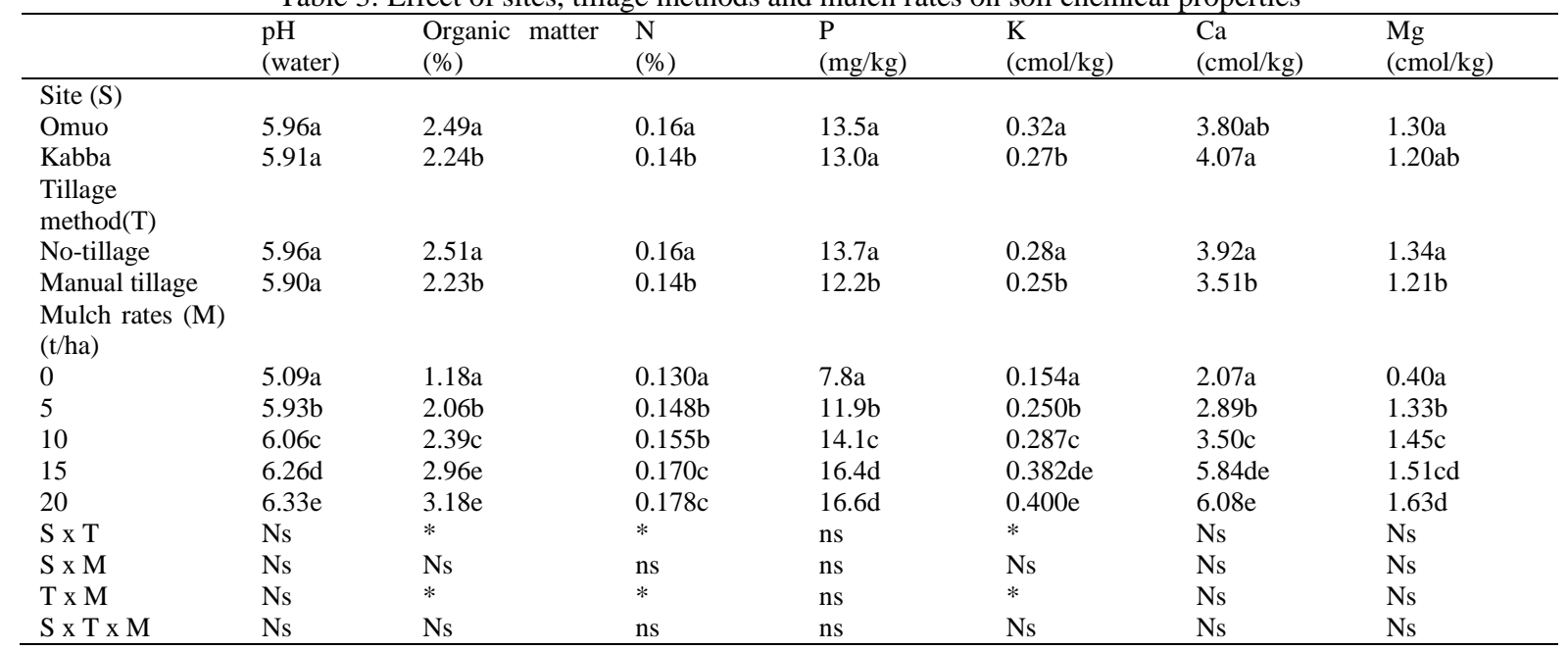

Values followed by similar letters under the same column are not significantly different at $p=0.05$ according to Duncan's multiple range test $(\mathrm{DMRT}) ; *=$ significant at $5 \%$ and $1 \%$ level of probability; $\mathrm{ns}=$ not significant

Table 4: Effect of sites, tillage methods and mulch rates on yield components of sweet potato

\begin{tabular}{|c|c|c|c|c|}
\hline & $\begin{array}{l}\text { Number of } \\
\text { tubers/plant }\end{array}$ & Tuber length $(\mathrm{cm})$ & $\begin{array}{l}\text { Tuber girth } \\
(\mathrm{cm})\end{array}$ & Tuber weight (t/ha) \\
\hline \multicolumn{5}{|l|}{ Site $(\mathrm{S})$} \\
\hline Omuo & $12.13 \mathrm{a}$ & $17.1 \mathrm{a}$ & $17.23 \mathrm{a}$ & $19.8 \mathrm{a}$ \\
\hline Kabba & $12.43 \mathrm{a}$ & $15.2 \mathrm{~b}$ & $16.30 \mathrm{ab}$ & $18.0 \mathrm{~b}$ \\
\hline \multicolumn{5}{|l|}{ Tillage method(T) } \\
\hline No-tillage (NT) & $12.31 \mathrm{a}$ & $15.39 \mathrm{a}$ & $16.88 \mathrm{a}$ & $20.2 \mathrm{a}$ \\
\hline Manual tillage (MT) & $12.25 \mathrm{a}$ & $15.15 \mathrm{a}$ & $16.58 \mathrm{a}$ & $17.3 b$ \\
\hline \multicolumn{5}{|l|}{ Mulch rate $(\mathrm{M})(\mathrm{t} / \mathrm{ha})$} \\
\hline 0 & $8.1 \mathrm{a}$ & $12.05 \mathrm{a}$ & $11.97 \mathrm{a}$ & $14.3 \mathrm{a}$ \\
\hline 5 & $11.1 \mathrm{~b}$ & $14.53 b$ & $15.83 b$ & $18.0 \mathrm{~b}$ \\
\hline 10 & $12.8 \mathrm{c}$ & $15.19 b$ & $16.87 \mathrm{~b}$ & $19.0 \mathrm{c}$ \\
\hline 15 & $14.3 \mathrm{~d}$ & $16.77 \mathrm{c}$ & $18.67 \mathrm{~cd}$ & $22.6 \mathrm{de}$ \\
\hline 20 & $15.4 \mathrm{e}$ & $16.82 \mathrm{c}$ & $19.33 d$ & $23.1 \mathrm{e}$ \\
\hline $\mathrm{S} \times \mathrm{T}$ & ns & ns & Ns & $*$ \\
\hline $\mathrm{S} \times \mathrm{M}$ & ns & ns & Ns & ns \\
\hline $\mathrm{T} \times \mathrm{M}$ & ns & ns & Ns & ns \\
\hline $\mathrm{S} \times \mathrm{T} \times \mathrm{M}$ & ns & ns & Ns & ns \\
\hline
\end{tabular}

Values followed by similar letters under the same column are not significantly different at $\mathrm{p}=0.05$ according to Duncan's multiple range test $(\mathrm{DMRT}) ; *=$ significant at $5 \%$ and $1 \%$ level of probability; ns = not significant

\section{Effect of sites, tillage methods and mulch application on yield components of sweet potato}

Data in Table 4 shows the results of the effect of sites, tillage methods and mulch application on yield components of sweet potato. Tuber weight and tuber length of sweet potato were higher significantly at Omuo compared with Kabba. Number of tubers per plant produced no significant result between Omuo and Kabba. Omuo site produced higher tuber girth of sweet potato that was not significantly different from Kabba site. Omuo site had 1.8 t/ha (10\%) higher sweet potato yield compared with Kabba site. 
Number of tubers per plant, tuber length and girth of sweet potato did not produce any significant value between NT and MT, but NT had significantly higher value of tuber weight compared with MT. In fact the yield difference between NT and MT was 2.9 t/ha $(16.7 \%)$.

Application of mulch increased the yield components of sweet potato significantly compared with no application. Increasing mulch level from 0-20 t/ha significantly increased number of tubers, tuber length, tuber girth and tuber weight of sweet potato. Tuber girth at 5 and $10 \mathrm{t} / \mathrm{ha}$ mulch levels were similar statistically. There was also no significant difference in mulch application between 15 and $20 \mathrm{t} /$ ha for tuber length, girth and weight of sweet potato. The yield difference between no application of mulch and $20 \mathrm{t} / \mathrm{ha}$ mulch level was $8.8 \mathrm{t} / \mathrm{ha}(61.8 \%)$.

\section{Discussion}

Among tillage methods, NT had significant higher moisture content compared with MT. The higher moisture content of NT compared with MT is consistent with its lower porosity. The turbulent movement of atmospheric air into soil which enhanced water evaporation occurs through larger pores. Hillet et al. (1975) had earlier reported that no-till plots were protected by layer of low conductivity (dry soil) on the surface which reduces evaporation losses. Though not significant, the slight higher bulk density and lower porosity of NT compared with MT could be attributed to no-tillage and compaction. This implies that continuous exposure of untilled soil to rainfall without tillage will compact the soil and therefore increase the bulk density of the soil.

It was reported that mulch increased soil moisture content, porosity and reduced soil temperature and bulk density significantly compared with no application of mulch. The higher moisture and porosity and lower temperature associated with mulch could be adduced to reduction of evaporation losses. The reduction in bulk density observed in mulch plots compared with no mulch plots can be adduced to increase in SOM resulted from the degraded residues by soil microorganisms.

The reported improvement in soil physical properties as mulch rates increases from $0-20 \mathrm{t} / \mathrm{ha}$ could be adduced to increase in SOM as the mulch level increases. Opara-Nadi and Lal (1987) found that surface applied mulch at 4 to $6 \mathrm{t} / \mathrm{ha}$ created more favourable soil physical properties compared with low mulch rates on Alfisol of southwest Nigeria.

The results that Omuo site had significant values of SOM, total N and exchangeable K compared with Kabba site could be adduced to the initial chemical properties of the soil. Omuo site is inherently higher in SOM, N and K compared with Kabba site.

The significant higher values of SOM, N, P, K, Ca and Mg reported in NT compared with MT soils could be related to presence of organic matter. The low values of SOM, N, P, K, Ca and Mg recorded for MT compared with NT plots could also be due to inversion of top soil during land preparation which could have brought less fertile subsoil to the surface.

The results that mulch plots increased SOM, N, P, K, Ca and Mg compared with unmulch plots attested to the fact that the siam weed mulch is rich in these nutrients and affirmed that these nutrients are released into the soil by decomposed mulches. The increase in the values of SOM, N, P, K, Ca and Mg with applied rates of mulch could be due to increase in organic matter

It was reported that tuber weight and length of sweet potato were significantly higher at Omuo compared with Kabba. This can be related to the soil chemical properties of Omuo site. Omuo site had higher values of SOM, N and K compared with Kabba. $\mathrm{N}$ and $\mathrm{K}$ are very important for tuber crops especially potato. $\mathrm{K}$ is specifically important for tuber formation in crops (Ngongi, 1977;Obigbesan, 1973; Agbede et al. 2013). The higher tuber yield at Omuo site can also be related to its lower bulk density and higher porosity (though not significant) compared with Kabba site. The reduced bulk density and increased porosity would have enhanced soil aeration, resulting from both a greater soil surface to soil volume has enhanced root growth (tuber length) and nutrient uptake and tuber yield.

The significant higher value of tuber weight of potato in NT plots compared with MT plots could be related to the higher values of soil chemical properties and moisture content of NT compared with MT. The excess water in NT compared with MT and soil nutrients especially $\mathrm{N}$ would also aid tuber expansion and water accumulation at the expense of starch formation and fresh matter formation. Whereas $\mathrm{K}$ availability would enhance starch formation.

The increase in yield components of sweet potato as a result of mulch application can be due to reduce bulk density and soil temperature and increase moisture content, porosity, SOM, N, P, K, Ca and Mg due to the mulch. The increase in the yield component of sweet potato as a result of increase in rates of mulch could be due to increase availability of SOM, N, P, K, Ca and Mg in the soil. It can also be adduced to the fact that moisture content and porosity increases and bulk density and temperature reduces as level of mulch increase, which means better soil structures are formed; better yield of potato. The non-significant between 15 and $20 \mathrm{t} / \mathrm{ha}$ mulch levels implies that the mulch at $15 \mathrm{t} / \mathrm{ha}$ is adequate for sweet potato and any further increase in mulch will be of no economic value. This is also the same as the soil chemical properties at this mulch level. Therefore no-tillage with 15 t/ha siam weed mulch is suitable for sweet potato production.

\section{Conclusion}

Differences in soil chemical properties ( $\mathrm{SOM}, \mathrm{N}$ and $\mathrm{K}$ ) caused by the initial soil properties induces variation in the tuber weight and length between Omuo and Kabba sites. No-tillage treatment had higher moisture content, SOM, N, P, 
$\mathrm{K}, \mathrm{Ca}$ and $\mathrm{Mg}$ compared with manual tillage, hence higher tuber yield. Application of mulch increases the yield components of sweet potato compared with no mulch application. The increase in yield as mulch rates increases was adduced to increase in soil organic matter from the mulch. There were however no significant differences between 15 and $20 \mathrm{t} / \mathrm{ha}$ mulch levels. Mulch applied at $15 \mathrm{t} / \mathrm{ha}$ was found to be suitable for sweet potato in tropical Alfisol. Therefore for soil fertility conservation and performance of sweet potato, no-tillage and $15 \mathrm{t} / \mathrm{ha}$ siam weed mulch is recommended.

\section{References}

Adekiya AO, Ojeniyi SO. 2002. Evaluation of tomato growth and soil properties under method of seedling bed preparation in an Alfisol in the rainforest zone of southwest Nigeria. Soil Tillage Res. 64:275-279.

Adekiya AO, Ojeniyi SO. 2011. Soil physical properties and cocoyam performance as influenced by tillage on an Alfisol in southwest Nigeria. Nigerian Journal of Soil Science 21 (1): 16-21.

Agbede TM. 2008. Nutrient availability and cocoyam yield under different tillage practices. Soil Tillage Res. 99 (1):49-57.

Agele SO, Iremiren GO, Ojeniyi SO. 1999. Effect of plant density and mulching on the performance of late season tomato (Lycopersicon esculentum Mill), in southern Nigeria. Journal of Agricultural Science 134: 55-59.

Akinrinde EA, Obigbesan GO. 2000. Evaluation of the fertility status of selected soils for crop production in five ecological zones of Nigeria. Proceedings of the 26th Annual Conference of Soil Science Society of Nigeria, Ibadan, Nigeria, pp. 279-288.

Ano AO, Agwu JA. 2005. Effect of animal manures on selected soil chemical properties (1). Nigerian Journal of Soil Science 15: 14-19.

Bremner JM. 1996. Nitrogen-total. In: D. L. Sparks (Ed.). Methods of Soil Analysis. Part 3. Chemical Methods. 2nd edition, SSSA Book Series No. 5, ASA and SSSA, Madison, WI, USA. pp. 1085-1121.

Campbell DJ, Henshall JK. 1991. Bulk density. In: K. A. Smith and C. E. Mullins (Eds.). Physical Method of Soil Analysis. Marcel Dekker, New York. pp. 329-366.

Carter MR. 1993. Soil Sampling and Methods of Analysis. Canadian Society of Soil Science, Lewis Publishers, London, 823pp.

Frank K, Beegle D, Denning J. 1998. Phosphorus. In: Brown, J.R. (Ed.), Recommended Chemical Soil Test Procedures for the North Central Region, NorthCentral Regional Research Publication No. 221 (revised), Missouri Agric. Exp. Stn., Columbia, MO. pp. 21-26.

Hendershot WH, Lalande H.1993. Ion exchange and exchangeable cations. In: M.R.Carter (Ed.), Soil Sampling and Methods of Analysis. Canadian Society of Soil Science, Lewi Publishers, London. vol. 19:167-176

Hillet DI, Van Bavel CHM, Talpas H. 1975. Dynamic stimulation of water storage in fallow soil as affected by mulch of hydrophobic aggregates. Soil Sci. Soc. Amer. Proc. 39:826-833.

Nelson DW, Sommers LE. 1996. Total carbon, organic carbon and organic matter. In: D.L. Sparks (Ed.), Methods of Soil Analysis. Part 3. 2nd ed., SSSA Book Series No. 5, SSSA, Madison, WI., USA. pp. 961-1010.

Ngongi AGN, Howeler RW, Macdonald HA.1977. Effect of potassium and sulphur on growth, yield and composition of cassava. In Proceedings of 4th Symposium of the International Society for Tropical Root Crops, pp. 107-113.

Obigbesan GO. 1973. The influence of potassium nutrition on the yield and chemical composition of some tropical root and tuber crops. In Int. Potash Inst., Colloquium, 10th Abidjan, Ivory Coast, pp. 439-451.

Ojeniyi SO. 2000. Effect of goat manure on soil nutrients and okra yield in a rainforest area of Nigeria. Applied Tropical Agriculture 5: 20-23.

Opara-Nadi O, Lal R.1987. Effects of no-till and ploughing with and without residue mulch on tropical root crops in southeastern Nigeria. Soil Tillage Research 9: 231-240.

Ossom EM, Pace PF, Rhykerd RL, Phykerd CL. 2001. Effect of mulch on weed infestation, soil temperature, nutrient concentration and tuber yield in Ipomoea batatas (L.) Lam. In Papua New Guinea. Trop. Agric. (Trinidad), 78: 144-151.

Osundare B. 2004. Effects of fertilizer types and different companion crops on the performance of sweet potato. Moor J. Agric. Res. 5:88-94.

Sheldrick B, Hand Wang C. 1993. Particle-size distribution. In: M.R. Carter (Ed.), Soil Sampling and Methods of Analysis. Canadian Society of Soil Science, Lewis Publishers, Ann Arbor MI. pp. 495-511.

Woolfe JA. 1992. Sweet potato an untapped food resources. Cambridge University Press, Cambridge, UK.643pp.

Yasmin F, Othman R, Sijam K, Saad MS. 2007. Effect of PGPR inoculation on growth and yield of sweet potato. J. Biol. Sci. 7: $421-424$. 